\begin{tabular}{lr}
\hline PRACE NAUKOWE UNIWERSYTETU EKONOMICZNEGO WE WROCLAWIU \\
RESEARCH PAPERS OF WROCLAW UNIVERSITY OF ECONOMICS & nr 472 • 2017 \\
\hline Dylematy zarządzania kosztami i dokonaniami & ISSN $1899-3192$ \\
& e-ISSN 2392-0041
\end{tabular}

\author{
Marek Gajewski \\ Uniwersytet Ekonomiczny we Wrocławiu \\ e-mail: p.pl@onet.pl
}

\title{
Grzegorz Gajewski
}

Szkoła Główna Handlowa w Warszawie

e-mail: gg23181@shg.waw.pl

\section{ZASTOSOWANIE RACHUNKU KOSZTÓW DO PODEJMOWANIA DECYZJI DLUGOOKRESOWYCH PODMIOTÓW LECZNICZYCH \\ THE USAGE OF THE COST CALCULATION AT MEDICAL ENTITIES FOR LONG-TERM DECISIONS}

DOI: $10.15611 /$ pn.2017.472.06

JEL Classification: M4, M40, I1, I15, C5, C54

Streszczenie: Trwające prace legislacyjne w 2017 roku wprowadzą szereg zmian w funkcjonowaniu polskiego systemu ochrony zdrowia. Najważniejszą z nich jest modyfikacja finansowania świadczeń zdrowotnych ze środków publicznych. Autor zwraca uwagę, że w Polsce w ostatnich latach wykreował się sieciowy układ podmiotów leczniczych. Na przykładzie danych finansowych otrzymanych od pojedynczego podmiotu leczniczego - będącego elementem takiej sieci - przeprowadzono na gruncie praktycznym scenariuszową analizę wyniku ze sprzedaży związanego z modelem rachunku kosztów pełnych i zmiennych. Otrzymane wnioski sugerują, że duże sieci podmiotów leczniczych, które zostaną pozbawione finansowania ze środków publicznych, będą miały w nowych uwarunkowaniach prawnych możliwość maksymalizacji zysku nie tylko poprzez poprawę jakości udzielanych świadczeń zdrowotnych, ale także przez podwyżkę cen sprzedaży usług zdrowotnych.

Słowa kluczowe: polski system ochrony zdrowia, rachunek kosztów, finansowanie świadczeń zdrowotnych.

Summary: Ongoing legislative work in 2017 will introduce a number of changes in the functioning of the Polish health care system. The most important of these is the change in the method of financing health services from public funds. The author notes that in Poland a network system has been created in recent years. Using some financial data scenario analysis was carried out with the usage of the the cost calculaton (full of variables). The results suggest that large chains will have the opportunity to maximize profits, not only by improving the quality of health services, but primarily by raising prices.

Keywords: Polish health care system, cost calculation, financing of medical services. 


\section{Wstęp}

$\mathrm{Na}$ przestrzeni ostatnich lat zasady funkcjonowania polskiego systemu ochrony zdrowia były kilkakrotnie zmieniane. Jego podstawą jest deklaracja państwa zawarta w art. 68 Konstytucji RP, według której obywatele mają zagwarantowany bezpłatny dostęp do świadczeń zdrowotnych. Nie ma natomiast precyzyjnych wytycznych - są one zawarte w przepisach wykonawczych, które podlegają cyklicznym modyfikacjom.

Jak do tej pory byliśmy świadkami utworzenia regionalnych kas chorych, następnie ich likwidacji i powołania w to miejsce Narodowego Funduszu Zdrowia. W 2017 roku zostało zapowiedziane zlikwidowanie NFZ-u i wprowadzenie kolejnych zmian.

Niezmiernie dyskusyjna jest efektywność funkcjonowania polskiego systemu ochrony zdrowia. W 2015 roku w rankingu Europejskiego Konsumenckiego Indeksu Zdrowia (Euro Health Consumer Index) Polska zajmowała przedostanie, 33. miejsce [www.healthpowerhouse.com].

Przedmiotem artykułu jest przedstawienie możliwości zastosowania modelu rachunku kosztów pełnych i zmiennych przez podmioty lecznicze do optymalizacji działań krótko- i długookresowych w kontekście planowanych zmian systemowych. Zwrócono również uwagę, że wykreowało się nowe zjawisko w polskim systemie ochrony zdrowia - sieci utworzone przez grupę podmiotów leczniczych mogą wyznaczyć własny kierunek działań, opierając się na swoich nośnikach wartości, które mogą być rozbieżne z wolą ustawodawcy. Zamiast minimalizacji zużycia zasobów w świadczeniu świadczeń zdrowotnych będą maksymalizować swój wynik finansowy.

W pracy wykorzystano metodę analizy literatury oraz aktów prawnych. Do badań materiałów źródłowych wykorzystano metodę analizy i syntezy.

\section{Zmiany w systemie ochrony zdrowia wpływające na działalność podmiotów leczniczych}

W roku 2017 planowane jest wdrożenie następujących zmian w systemie ochrony zdrowia:

- utworzenie 6-stopniowej sieci szpitali, które będą miały zagwarantowane ryczałtowe finansowanie ze środków publicznych; oznacza to, że pozostałe podmioty otrzymają mniej środków finansowych,

- zwiększenie dostępności do podstawowej opieki zdrowotnej na podstawie oświadczenia pacjentów o posiadaniu uprawnień do świadczeń, działając w dobrej woli nie będą oni obciążeni kosztami leczenia w przypadku braku ubezpieczenia zdrowotnego, 
- ujednolicenie bazy danych gromadzącej informacje o edukacji podyplomowej lekarzy, pielęgniarek i położnych, diagnostów laboratoryjnych, ratowników medycznych oraz farmaceutów, utworzenie jednolitego systemu monitorowania kształcenia pracowników medycznych ma na celu usprawnienie elektronicznej weryfikacji kwalifikacji personelu medycznego przy rozliczaniu świadczeń zdrowotnych,

- nowe uprawnienia lekarzy stażystów, mogą oni mogli wystawiać skierowania na rutynowe badania, udzielać informacji o zdrowiu pacjenta bez konsultacji z lekarzem prowadzącym, natomiast uzupełnianie dokumentacji medycznej, wystawienie recept ma być nadal dokonywane po konsultacji z lekarzem prowadzącym,

- zakończenie prac mających na celu dostosowanie pomieszczeń i urządzeń podmiotów leczniczych do obowiązujących już wymogów technicznych i sanitarnych,

- podwyżki wynagrodzeń personelu medycznego, od 31.12.2019 roku ma obowiązywać najniższe wynagrodzenie dla lekarzy w wysokości 4953 zł brutto,

- podwyżki wynagrodzeń dla osób zarządzających podmiotami leczniczymi, które mają uwzględniać skalę działalności podmiotu leczniczego,

- obowiązkowe raportowanie o bieżącej sytuacji ekonomiczno-finansowej samodzielnego publicznego zakładu opieki zdrowotnej oraz przygotowanie planu finansowego na następne 3 lata obrotowe przez dyrektorów dla organów tworzących SP ZOZ-y,

- wdrożenie elektronicznej formy prowadzenia dokumentacji medycznej, której termin wdrożenia był już dwukrotnie przesuwany.

Podsumowując, wprowadzenie wyszczególnionych zmian spowoduje radykalną zmianę zasad funkcjonowania systemu ochrony zdrowia. Obecnie trudno oszacować skutki ich wdrożenia, określić, czy rzeczywiście ich implementacja poprawi skuteczność leczenia, zwiększy dostępność do świadczeń zdrowotnych.

Należy zwrócić uwagę na fakt, że dopiero od 2015 roku zostały określone zalecenia dotyczące zasad gromadzenia danych o kosztach działalności przez podmioty lecznicze oraz metody kalkulacji kosztów świadczeń zdrowotnych ${ }^{1}$. Dotyczą one przede wszystkim tych podmiotów, które współpracują z Agencją Technologii Medycznych i Taryfikacji i są finansowane ze środków publicznych.

Skutkuje to tym, że obecnie bardzo utrudnione jest wzajemne porównywanie danych o kosztach działalności podmiotów leczniczych wedle poszczególnych kategorii kosztów, jak również utrudniona jest realna wycena świadczeń zdrowotnych

1 Rozporządzenie Ministra Zdrowia z dnia 8 lipca 2015 r. w sprawie zaleceń dotyczących standardu rachunku kosztów u świadczeniodawców (Dz.U. z 2015 r., poz. 1126). Poprzednie Rozporządzenie Ministra Zdrowia i Opieki Społecznej z dnia 22 grudnia 1998 r. w sprawie szczególnych zasad rachunku kosztów w publicznych zakładach opieki zdrowotnej (Dz.U. z 1998 r., nr 164, późn. 1194) zostało anulowane w 2011 r. z chwilą wejścia w życie Ustawy z dnia 15 kwietnia 2011 r. o działalności leczniczej. 
przez ustawodawców, kadrę podmiotów leczniczych oraz innych badaczy. Wydaje się również, że będzie trudne do oszacowania, czy wprowadzenie planowanych zmian spowodowało obniżenie, czy wzrost jednostkowych cen świadczeń zdrowotnych, ponieważ nie ma danych wyjściowych do prowadzenia takich analiz obejmujących cały system ochrony zdrowia.

\section{Sieci podmiotów leczniczych}

Autor zwraca uwagę, że w trakcie wprowadzania kolejnych zmian legislacyjnych na przestrzeni ostatnich kilkunastu lat samoczynnie wykreował się w Polsce sieciowy układ podmiotów leczniczych.

Ustanowione w 2011 r. zmiany legislacyjne [Ustawa z 15 kwietnia 2011] wprowadziły mechanizm komercjalizacji podmiotów leczniczych, które generowały ujemne przepływy finansowe. Samodzielne publiczne zakłady opieki zdrowotnej były przekształcane w spółki prawa handlowego, których udziały większościowe były następnie sprzedawane podmiotom prywatnym. Organy tworzące miały możliwość zatrzymania części udziałów i tym samym partycypacji w budowaniu strategii podmiotów leczniczych i dalszym zapewnianiu dostępu do świadczeń zdrowotnych mieszkańcom danego regionu, gminy, powiatu. Zakładano, że to rozwiązanie zaowocuje zmniejszeniem poziomu zadłużenia zakładów opieki zdrowotnej, gdyż prywatny podmiot będzie racjonalizował koszty swojej działalności²

Zakładając, że przekształceniu w spółki prawa handlowego i prywatyzacji podlegały podmioty, których sytuacja finansowo-ekonomiczna była zła, wydaje się, że było to właściwe rozwiązanie - w ówczesnych uwarunkowaniach - aby mogły one dalej istnieć i nadal leczyć pacjentów. Jednakże skutki takich decyzji nie były w pełni określone.

Na rysunku 1 przedstawione są etapy budowania układu sieciowego. Zgodnie z koncepcją K. Perechudy przedsiębiorstwa mogą tworzyć swoją wartość poprzez budowanie sieci kontaktów, oddziałów. W końcowej fazie powstaje sieć elementów strategicznych, wokół których skoncentrowane są mniejsze elementy. Taka struktura umożliwia szybkie przesyłanie informacji pomiędzy podmiotami dominującymi, które następnie oddziałują na elementy, które je otaczają. Pozwala to na ukierunkowanie działań, a także szybką odpowiedź sieci na wyzwania otoczenia.

Zjawisko tworzenia sieci w Polsce można zaobserwować na przykładzie powiązań podmiotów leczniczych tworzących kompleksową opiekę medyczną na obszarze Dolnego Śląska przez podmioty niepubliczne - EMC Instytut Medyczny S.A. Jest to przedstawione na rysunku 2.

${ }^{2} \mathrm{Na}$ występowanie zjawiska niedoszacowania wartości świadczeń zdrowotnych, które skutkowało nadmiernym zadłużaniem się samodzielnych publicznych zakładów opieki zdrowotnej zwrócił uwagę W. Dotkuś [2006]. 


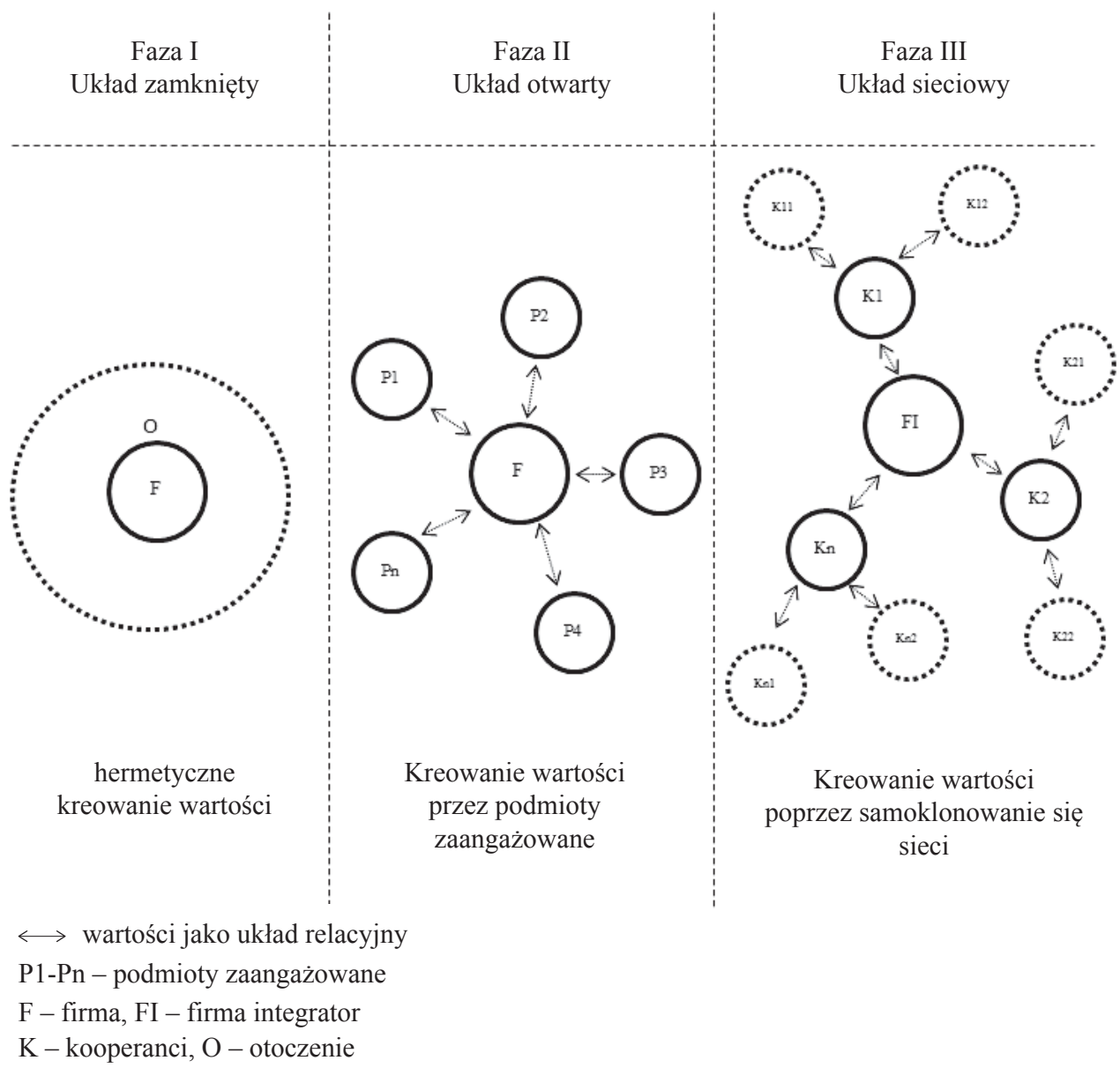

Rys. 1. Strategie kreowania wartości w podstawowych fazach rozwoju firmy

Źródło: [Perechuda 2007, s. 119].

Taki układ sieciowy umożliwia zmniejszenie kosztów działalności poprzez koordynację działań. Na przykład podmiot dominujący przejmuje realizację funkcji administracyjnych, zarządczych. Pozwala również na udzielanie różnorodnych świadczeń zdrowotnych pacjentom, podmioty tworzące sieć uzupełniają się wzajemnie. Jednocześnie należy zwrócić uwagę, że tak funkcjonująca struktura, jeśli będzie utworzona przez odpowiednio dużą liczbę podmiotów leczniczych, może samodzielnie określać warunki, na których będą udzielane świadczenia zdrowotne, wyznaczać ceny świadczeń. Układy sieciowe mają możliwość szybkiego reagowania na zmiany, a nawet podejmowania działań wyprzedzających w odpowiednio dużej skali. 


\section{MODEL SIECI OPIEKI MEDYCZNEJ EMC INSTYTUT MEDYCZNY S A NA DOLNYM ŚLĄSKU}

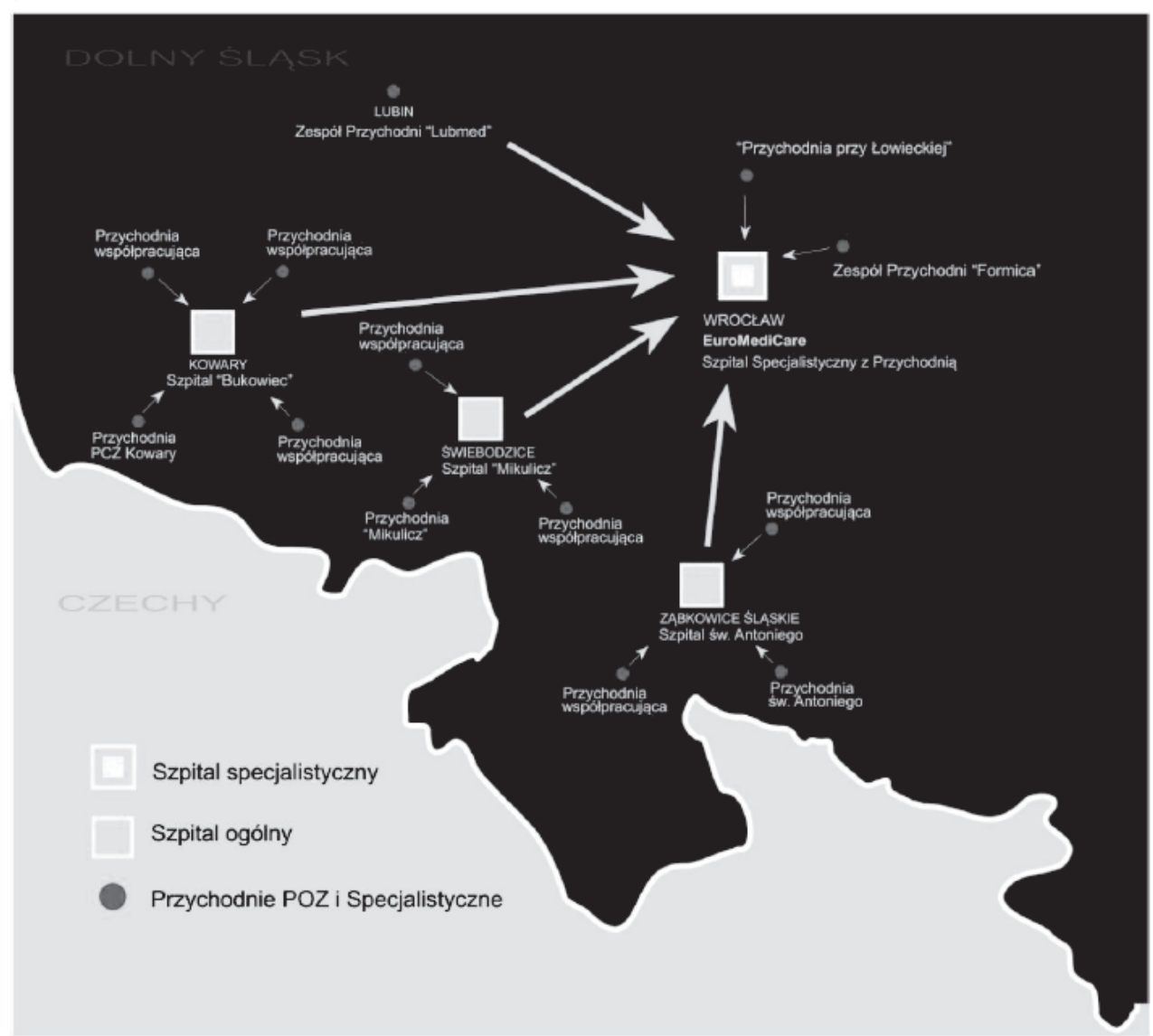

Rys. 2. Model sieci podmiotów leczniczych Źródło: http://www.emc-sa.pl (28.10.2013).

\section{Rola rachunku kosztów w podejmowaniu decyzji długoterminowych przez podmioty lecznicze}

Analiza efektów działań podmiotu leczniczego została przeprowadzona z wykorzystaniem danych finansowych za 2015 rok. Zweryfikowano dwa scenariusze decyzyjne. Pierwszy obejmował zwiększenie ceny świadczonych usług zdrowotnych bez podejmowania dodatkowych nakładów inwestycyjnych, modernizacji majątku trwałego. Drugi uwzględniał zmianę struktury kosztów - obniżenie kosztów sta- 
łych - poprzez wymianę urządzeń medycznych na bloku operacyjnym, zwiększenie poziomu automatyzacji procesów. Obniżka kosztów stałych w tym przypadku wynika m.in. z mniejszego zaangażowania personelu, mniejszej powierzchni, niższych kosztów przeglądów medycznych.

Jednocześnie przyjęto założenie, że za przychody ze sprzedaży uznane są świadczenia, za które podmiot leczniczy otrzymał środki finansowe od Narodowego Funduszu Zdrowia, z którym zawarł umowę o finansowanie świadczeń ze środków publicznych. Reguluje ona cenę za punkt oraz ilość świadczeń zdrowotnych - przeliczanych na punkty, które mogą być udzielone w danym roku. Oznacza to, że w przypadku przekroczenia ustalonych limitów, wystąpienia tzw. nadwykonań, są one pomijane, gdyż podmiot leczniczy nie otrzymał za nie środków finansowych. Nie występuje zatem kategoria „niesprzedanych usług”, wyniki ze sprzedaży kalkulowane według rachunku kosztów pełnych i zmiennych są zbieżne.

Na prośbę zarządzających nazwa podmiotu leczniczego, którego dane o kosztach są przedstawione $\mathrm{w}$ niniejszym artykule, nie zostanie podana. Podmiot leczniczy ma znaczącą rolę na rynku lokalnym. Jest również podmiotem współtworzącym sieć podmiotów leczniczych pewnej określonej grupy kapitałowej. Realizuje świadczenia zdrowotne z różnych zakresów, specjalności przez następujące oddziały specjalistyczne:

- Oddział Wewnętrzny,

- Oddział Pediatryczny,

- Oddział Ginekologiczno-Położniczy z Neonatologią,

- Oddział Chirurgiczny z Pracownią Endoskopową,

- Zakład Opiekuńczo-Leczniczy,

- Rehabilitacja Ogólnoustrojowa i Neurologiczna,

- Zakład Rehabilitacji Ambulatoryjnej i Poradnia Rehabilitacyjna,

- Oddział Leczenia Nerwic,

- Hospicjum,

- Przychodnia,

- Izba Przyjęć.

W tabeli 1 przedstawiona jest wielostopniowa kalkulacja wyniku ze sprzedaży według kosztów zmiennych [Nowak, Wierzbicki 2010, s. 36-85]. Dla wszystkich oddziałów przychody ze sprzedaży pokrywają koszty zmienne oddziału oraz zmienne koszty pośrednie. Natomiast po uwzględnieniu stałych kosztów oddziałów Oddział Ginekologiczno-Położniczy z Neonatologią generuje stratę (marża na pokrycie V). Po uwzględnieniu stałych kosztów pośrednich jest ujemny wynik ze sprzedaży dodatkowo dla Izby Przyjęć oraz Oddziału Chirurgicznego z Pracownią Endoskopową. Kluczowym czynnikiem generującym koszty w podmiocie leczniczym jest sala operacyjna. Koszty jej funkcjonowania obciążają Oddział Ginekologiczny oraz Oddział Chirurgiczny. Natomiast po uwzględnieniu kosztów ogólnozakładowych wynik ze sprzedaży jest równy stracie w wysokości około 515 tys. zł. 
Tabela 1. Wielostopniowy rachunek wyników podmiotu leczniczego oparty na modelu kosztów zmiennych - rok 2015

\begin{tabular}{|c|c|c|c|c|c|c|c|c|c|c|c|c|c|}
\hline Lp. & $\begin{array}{l}\text { Wielostopniowy } \\
\text { rachunek wyników } \\
\text { podmiotu leczniczego } \\
\text { oparty na modelu } \\
\text { kosztów zmiennych } \\
\text { (2015 rok) }\end{array}$ & $\begin{array}{l}\text { Oddział } \\
\text { We- } \\
\text { wnętrzny }\end{array}$ & $\begin{array}{l}\text { Oddział } \\
\text { Pedia- } \\
\text { tryczny }\end{array}$ & $\begin{array}{c}\text { Oddział } \\
\text { Gineko- } \\
\text { logicz- } \\
\text { no-Po- } \\
\text { tożniczy } \\
\text { z Neona- } \\
\text { tologią }\end{array}$ & $\begin{array}{l}\text { Oddział } \\
\text { Chirur- } \\
\text { giczny } \\
\text { z Pra- } \\
\text { cownią } \\
\text { Endosko- } \\
\text { pową }\end{array}$ & $\begin{array}{c}\text { Zakład } \\
\text { Opie- } \\
\text { kuńczo- } \\
\text {-Leczni- } \\
\text { czy }\end{array}$ & $\begin{array}{l}\text { Rehabi- } \\
\text { litacja } \\
\text { Ogólno- } \\
\text { ustrojowa } \\
\text { i Neuro- } \\
\text { logiczna }\end{array}$ & $\begin{array}{l}\text { Zakład } \\
\text { Rehabilita- } \\
\text { cji Ambu- } \\
\text { latoryjnej } \\
\text { i Poradnia } \\
\text { Rehabilita- } \\
\text { cyjna }\end{array}$ & $\begin{array}{c}\text { Od- } \\
\text { dział } \\
\text { Le- } \\
\text { czenia } \\
\text { Nerwic }\end{array}$ & $\begin{array}{l}\text { Hospi- } \\
\text { cjum }\end{array}$ & $\begin{array}{l}\text { Przy- } \\
\text { chodnia }\end{array}$ & $\begin{array}{c}\text { Izba } \\
\text { Przyjęć }\end{array}$ & SUMA \\
\hline 1 & Przychody ze sprzedaży & 2994656 & 885813 & 2654341 & 2400642 & 1585284 & 1438062 & 259032 & 619311 & 928455 & 3624457 & 675977 & 18066030 \\
\hline 2 & \begin{tabular}{|l|} 
Zmienne koszty \\
oddziału
\end{tabular} & 1117792 & 407908 & 1118979 & 1245910 & 552563 & 648316 & 87512 & 341047 & 375747 & 1418916 & 281634 & 7596324 \\
\hline 3 & Marża na pokrycie I & 1876863 & 477905 & 1535362 & 1154732 & 1032721 & 789746 & 171521 & 278264 & 552708 & 2205541 & 394343 & 10469706 \\
\hline 4 & \begin{tabular}{|l|} 
Zmienne koszty \\
pośrednie
\end{tabular} & 92630 & 9118 & 590913 & 597094 & 1073 & 22992 & 200 & 723 & 928 & 27386 & 14244 & 1357301 \\
\hline 5 & Marża na pokrycie II & 1784233 & 468786 & 944449 & 557638 & 1031648 & 766754 & 171321 & 277541 & 551780 & 2178154 & 380099 & 9112405 \\
\hline 6 & Koszty stałe oddziału & 931085 & 329483 & 983472 & 364624 & 833026 & 470721 & 108753 & 42254 & 439700 & 714267 & 344776 & 5562162 \\
\hline 7 & Marża na pokrycie IV & 853148 & 139304 & -39022 & 193014 & 198623 & 296033 & 62568 & 235287 & 112080 & 1463887 & 35323 & 3550243 \\
\hline 8 & Stałe koszty pośrednie & 124491 & 20906 & 369637 & 371072 & 13752 & 22539 & 2594 & 7860 & 10668 & 159995 & 83640 & 1187154 \\
\hline 9 & Marża na pokrycie V & 728657 & 118398 & -408659 & -178058 & 184870 & 273494 & 59974 & 227427 & 101411 & 1303892 & -48317 & 2363088 \\
\hline 10 & Łączne koszty zarządu & & & & & & & & & & & & 2878780 \\
\hline 10.1 & \begin{tabular}{|l|} 
Koszty nadzoru \\
laboratorium
\end{tabular} & & & & & & & & & & & & 14113 \\
\hline 10.2 & Koszty nadzoru kuchni & & & & & & & & & & & & 144207 \\
\hline 10.3 & \begin{tabular}{|l|} 
Koszty ogólnego \\
zarządu
\end{tabular} & & & & & & & & & & & & 2720460 \\
\hline 11 & Wynik ze sprzedaży & & & & & & & & & & & & -515692 \\
\hline
\end{tabular}

Źródło: opracowanie własne na podstawie danych otrzymanych od podmiotu leczniczego. 
Tabela 2. Scenariuszowa analiza wyniku ze sprzedaży przy wzroście stawki za punkt rozliczeniowy

\begin{tabular}{|c|c|c|c|c|c|c|c|c|c|c|c|c|c|}
\hline Lp. & $\begin{array}{l}\text { Rachunek wyników } \\
\text { podmiotu leczni- } \\
\text { czego oparty na } \\
\text { modelu kosztów } \\
\text { pełnych (2015 rok), } \\
\text { przy wzroście staw- } \\
\text { ki za punkt o 5\% } \\
\text { dla Oddziału Gine- } \\
\text { kologiczno-Położ- } \\
\text { niczego i Oddziału } \\
\text { Chirurgicznego } \\
\end{array}$ & $\begin{array}{l}\text { Oddział } \\
\text { We- } \\
\text { wnętrzny }\end{array}$ & $\begin{array}{l}\text { Oddział } \\
\text { Pedia- } \\
\text { tryczny }\end{array}$ & $\begin{array}{c}\text { Oddział } \\
\text { Ginekolo- } \\
\text { giczno- } \\
\text {-Położ- } \\
\text { niczy z } \\
\text { Neonato- } \\
\text { logią }\end{array}$ & $\begin{array}{l}\text { Oddział } \\
\text { Chirur- } \\
\text { giczny } \\
\text { z Pra- } \\
\text { cownią } \\
\text { Endosko- } \\
\text { pową }\end{array}$ & $\begin{array}{c}\text { Zakład } \\
\text { Opiekuń- } \\
\text { czo-Lecz- } \\
\text { niczy }\end{array}$ & $\begin{array}{l}\text { Rehabi- } \\
\text { litacja } \\
\text { Ogólno- } \\
\text { ustrojowa } \\
\text { i Neurolo- } \\
\text { giczna }\end{array}$ & $\begin{array}{c}\text { Zakład } \\
\text { Rehabi- } \\
\text { litacji } \\
\text { Ambu- } \\
\text { latoryj- } \\
\text { nej } \\
\text { i Po- } \\
\text { radnia } \\
\text { Rehabi- } \\
\text { litacyjna }\end{array}$ & $\begin{array}{l}\text { Oddział } \\
\text { Le- } \\
\text { czenia } \\
\text { Nerwic }\end{array}$ & $\begin{array}{l}\text { Hospi- } \\
\text { cjum }\end{array}$ & $\begin{array}{l}\text { Przychod- } \\
\text { nia }\end{array}$ & $\begin{array}{c}\text { Izba } \\
\text { Przyjęć }\end{array}$ & SUMA \\
\hline 1 & $\begin{array}{l}\text { Przychody ze } \\
\text { sprzedaży rozli- } \\
\text { czonych świadczeń } \\
\text { zdrowotnych } \\
\end{array}$ & 2994656 & 885813 & 2787058 & 2520674 & 1585284 & 1438062 & 259032 & 619311 & 928455 & 3624457 & 675977 & 18318779 \\
\hline 2 & $\begin{array}{l}\text { Pełne koszty wy- } \\
\text { tworzenia } \\
\text { produktów }\end{array}$ & 2265999 & 767415 & 3063000 & 2578700 & 1400414 & 1164568 & 199058 & 391884 & 827043 & 2320565 & 724294 & 15702941 \\
\hline 3 & $\begin{array}{l}\text { Koszty } \\
\text { bezpośrednie }\end{array}$ & 2048878 & 737391 & 2102451 & 1610534 & 1385588 & 1119037 & 196265 & 383301 & 815447 & 2133184 & 626410 & 13158486 \\
\hline 4 & Koszty wydziałowe & 217121 & 30024 & 960550 & 968166 & 14825 & 45531 & 2794 & 8583 & 11596 & 187381 & 97884 & 2544455 \\
\hline 5 & $\begin{array}{l}\text { Łączne koszty } \\
\text { zarządu }\end{array}$ & & & & & & & & & & & & 2878780 \\
\hline 5.1 & $\begin{array}{l}\text { Koszty nadzoru } \\
\text { laboratorium }\end{array}$ & & & & & & & & & & & & 14113 \\
\hline 5.2 & $\begin{array}{l}\text { Koszty nadzoru } \\
\text { kuchni }\end{array}$ & & & & & & & & & & & & 144207 \\
\hline 5.3 & $\begin{array}{l}\text { Koszty ogólnego } \\
\text { zarządu }\end{array}$ & & & & & & & & & & & & 2720460 \\
\hline 6 & Wynik ze sprzedaży & & & & & & & & & & & & -262942 \\
\hline
\end{tabular}

Źródło: opracowanie własne na podstawie danych otrzymanych od podmiotu leczniczego. 
Tabela 3. Scenariuszowa analiza wyniku ze sprzedaży przy dokonaniu inwestycji - obniżenie kosztów stałych Bloku Operacyjnego

\begin{tabular}{|c|c|c|c|c|c|c|c|c|c|c|c|c|c|}
\hline Lp. & $\begin{array}{l}\text { Wielostopniowy rachu- } \\
\text { nek wyników podmiotu } \\
\text { leczniczego oparty } \\
\text { na modelu kosztów } \\
\text { zmiennych ( } 2015 \text { rok) }\end{array}$ & $\begin{array}{c}\text { Oddział } \\
\text { We- } \\
\text { wnętrzny }\end{array}$ & $\begin{array}{l}\text { Oddział } \\
\text { Pedia- } \\
\text { tryczny }\end{array}$ & $\begin{array}{c}\text { Oddział } \\
\text { Gineko- } \\
\text { logicz- } \\
\text { no-Po- } \\
\text { łożniczy } \\
\text { z Neo- } \\
\text { natolo- } \\
\text { gią }\end{array}$ & $\begin{array}{l}\text { Oddział } \\
\text { Chirur- } \\
\text { giczny } \\
\text { z Pra- } \\
\text { cownią } \\
\text { Endo- } \\
\text { skopową }\end{array}$ & $\begin{array}{l}\text { Zakład } \\
\text { Opie- } \\
\text { kuńczo- } \\
\text {-Leczni- } \\
\text { czy }\end{array}$ & $\begin{array}{c}\text { Rehabi- } \\
\text { litacja } \\
\text { Ogólno- } \\
\text { ustro- } \\
\text { jowa } \\
\text { i Neuro- } \\
\text { logiczna }\end{array}$ & $\begin{array}{c}\text { Zakład } \\
\text { Rehabilita- } \\
\text { cji Ambu- } \\
\text { latoryjnej } \\
\text { i Poradnia } \\
\text { Rehabilita- } \\
\text { cyjna }\end{array}$ & $\begin{array}{l}\text { Oddział } \\
\text { Leczenia } \\
\text { Nerwic }\end{array}$ & $\begin{array}{l}\text { Hospi- } \\
\text { cjum }\end{array}$ & $\begin{array}{l}\text { Przychod- } \\
\text { nia }\end{array}$ & $\begin{array}{l}\text { Izba } \\
\text { Przyjęć }\end{array}$ & SUMA \\
\hline 1 & $\begin{array}{l}\text { Przychody ze sprzeda- } \\
\dot{z} y \text { - rozliczone }\end{array}$ & 2994656 & 885813 & 2654341 & 2400642 & 1585284 & 1438062 & 259032 & 619311 & 928455 & 3624457 & 675977 & 18066030 \\
\hline 2 & $\begin{array}{l}\text { Zmienne koszty } \\
\text { oddziału }\end{array}$ & 1117792 & 407908 & 1118979 & 1245910 & 552563 & 648316 & 87512 & 341047 & 375747 & 1418916 & 281634 & 7596324 \\
\hline 3 & $\begin{array}{l}\text { Marża na pokrycie I } \\
(1-2)\end{array}$ & 1876863 & 477905 & 1535362 & 1154732 & 1032721 & 789746 & 171521 & 278264 & 552708 & 2205541 & 394343 & 10469706 \\
\hline 4 & $\begin{array}{l}\text { Zmienne koszty } \\
\text { pośrednie }\end{array}$ & 92630 & 9118 & 615913 & 622094 & 1073 & 22992 & 200 & 723 & 928 & 27386 & 14244 & 1407301 \\
\hline 5 & $\begin{array}{l}\text { Marża na pokrycie II } \\
(3-4)\end{array}$ & 1784233 & 468786 & 919449 & 532638 & 1031648 & 766754 & 171321 & 277541 & 551780 & 2178154 & 380099 & 9062405 \\
\hline 6 & Koszty stałe oddziału & 931085 & 329483 & 983472 & 364624 & 833026 & 470721 & 108753 & 42254 & 439700 & 714267 & 344776 & 5562162 \\
\hline 7 & $\begin{array}{l}\text { Marża na pokrycie IV } \\
(5-6)\end{array}$ & 853148 & 139304 & -64022 & 168014 & 198623 & 296033 & 62568 & 235287 & 112080 & 1463887 & 35323 & 3500243 \\
\hline 8 & Stałe koszty pośrednie & 124491 & 20906 & 279894 & 281329 & 13752 & 22539 & 2594 & 7860 & 10668 & 159995 & 83640 & 1007669 \\
\hline 9 & Marża na pokrycie V & 728657 & 118398 & -343917 & -113315 & 184870 & 273494 & 59974 & 227427 & 101411 & 1303892 & -48317 & 2492574 \\
\hline 10 & Łączne koszty zarządu & & & & & & & & & & & & 2878780 \\
\hline 10.1 & $\begin{array}{l}\text { Koszty nadzoru } \\
\text { laboratorium }\end{array}$ & & & & & & & & & & & & 14113 \\
\hline 10.2 & Koszty nadzoru kuchni & & & & & & & & & & & & 144207 \\
\hline 10.3 & $\begin{array}{l}\text { Koszty ogólnego } \\
\text { zarządu }\end{array}$ & & & & & & & & & & & & 2720460 \\
\hline 11 & Wynik ze sprzedaży & & & & & & & & & & & & -386206 \\
\hline
\end{tabular}

Źródło: opracowanie własne na podstawie danych otrzymanych od podmiotu leczniczego oraz [Nowak 2016, s.178; Trentkowska 2015, s. 190-193; Nowak, Wierzbicki 2010, s. 72-75]. 
Taka forma prezentacji danych o kosztach pozwala uchwycić zależności pomiędzy poszczególnymi kategoriami kosztów oraz określić rentowności poszczególnych oddziałów.

W tabeli 2 przedstawione są dane przy zwiększeniu przychodów ze sprzedaży o 5\% dla dwóch oddziałów, które generowały największe straty: Oddziału Ginekologiczno-Położniczego i Oddziału Chirurgicznego. Zwiększenie ceny sprzedaży świadczeń skutkuje zmniejszeniem straty z poziomu 515 tys. do 216 tys. złotych.

$\mathrm{W}$ wariancie przedstawionym w tabeli 3 podmiot leczniczy rozważa modernizację, wymianę sprzętu medycznego oraz automatyzację procesów na Bloku Operacyjnym. W wyniku czego następuje spadek kosztów stałych w skali roku o 180 tys. zł, jednocześnie generowane są dodatkowe koszty zmienne w wysokości 50 tys. zł.

W przypadku przeprowadzenia tej inwestycji, po zmianie struktury kosztów podmiot generuje stratę w wysokości 386 tys. zł. Koszty wdrożenia inwestycji zostały pominięte, gdyż nie stanowią one kosztów okresu, lecz są rozłożone w czasie. Prowadząc szczegółowe analizy opłacalności inwestycji, należałoby je uwzględnić.

Zaproponowana analiza wyników ze sprzedaży związanych z modelem rachunku kosztów pełnych i zmiennych umożliwia ocenę skutków działań. W analizowanym przypadku zweryfikowano dwa scenariusze decyzyjne: pierwszy ukierunkowany na maksymalizację zysku przez podmiot leczniczy (typowy dla podmiotów prywatnych), drugi zmierzający do optymalnego wykorzystania zasobów w ramach przyznanych limitów finansowania ze środków publicznych (właściwy dla podmiotów publicznych).

\section{Zakończenie}

Porównując efekty możliwych do realizacji scenariuszy dla badanego podmiotu leczniczego, optymalnym kierunkiem działań - przy dążeniu do maksymalizacji zysku - jest stworzenie modelu biznesowego opierającego się głównie na zwiększeniu cen sprzedaży świadczeń zdrowotnych, zamiast rozbudowywania infrastruktury i zwiększania jakości udzielanych świadczeń. Autor określa jako decyzje długoterminowe te działania, które dotyczą zdefiniowania modelu biznesowego podmiotu leczniczego w perspektywie wieloletniej, na który składają się: określenie rodzaju udzielanych świadczeń, rozbudowywanie, modernizowanie zaplecza technicznego, wdrażanie nowych technologii, przygotowywanie osób do wykonywania zawodu medycznego ${ }^{3}$. Jednocześnie należy zwrócić uwagę, że na rynku świadczeń zdrowotnych obecnie są podmioty zróżnicowane pod względem: zakresu działalności, formy organizacyjno-prawnej, formy własności [Chluska 2014, s. 17]. Przy podobnych uwarunkowaniach otoczenia, źródle i poziomie finansowania będą one podejmowały odmienne decyzje długoterminowe.

${ }^{3}$ M. Hass-Symotiuk zwraca uwagę, że zakres działalności podmiotów leczniczych obejmuje udzielanie świadczeń, promocję zdrowia oraz działalność dydaktyczną i badawczą [Hass-Symotiuk 2014, s. 13-14]. 
Pojedynczy podmiot leczniczy, związany umową z Narodowym Funduszem Zdrowia oraz uwarunkowaniami lokalnego rynku, może mieć bardzo ograniczone możliwości podniesienia cen. Natomiast odpowiednio liczna grupa podmiotów leczniczych, w szczególności działająca w dużej zorganizowanej sieci, obejmującej region czy kraj, może narzucić wyższe ceny na wytypowane przez siebie rodzaje świadczeń zdrowotnych. Może tego dokonać nawet wobec publicznego płatnika składek. Może również podjąć decyzję o wyjściu z systemu finansowania świadczeń zdrowotnych ze środków publicznych i żądać opłat od pacjentów indywidualnych. I. Rudawska zwraca uwagę na proces starzenia się społeczeństwa Europy. Zmieniający się profil zdrowotny będzie miał wpływ na zwiększanie się popytu na świadczenia udzielane przez podmioty lecznicze, co dodatkowo wzmocni ich pozycję rynkową względem pacjentów czy instytucji dysponującej środkami publicznymi przeznaczonymi na finansowanie świadczeń zdrowotnych [Rudawska 2015, s. 53].

Oznacza to, że wprowadzenie zapowiedzianych w roku 2017 zmian może skutkować trudnymi obecnie do oszacowania rezultatami. Wydaje się, że po wejściu w życie regulacji dotyczących technicznych warunków pomieszczeń i urządzeń medycznych, kształcenia personelu medycznego, warunków pracy wszyscy uczestnicy rynku będą musieli je respektować - będą musieli dostosować się do nowych zasad.

Natomiast niejednoznaczny jest efekt wprowadzenia przepisów dotyczących zakresu gwarantowanych świadczeń zdrowotnych, ich wyceny oraz finansowania, w szczególności ustanowienie 6-stopniowej sieci publicznych szpitali i wyłączenie z obszaru finansowania ze środków publicznych skomercjalizowanych podmiotów leczniczych.

W analizowanym obszarze nakładają się na siebie dwie grupy czynników: pierwsza związana z poziomem finansowania świadczeń zdrowotnych ze środków publicznych; druga to siła oddziaływania grup podmiotów leczniczych - działających w formie sieci - na system ochrony zdrowia. Autor zwraca również uwagę na szerokie możliwości zastosowania rachunku kosztów pełnych i zmiennych do oceny efektów działań podmiotów leczniczych.

\section{Literatura}

Chluska J., 2014, Rachunkowość podmiotów leczniczych, Wolters Kluwer S.A., Warszawa.

Dotkuś W., 2006, Pomiar zadtużenia w publicznych zakładach opieki zdrowotnej województwa dolnośląskiego, Wydawnictwo Akademii Ekonomicznej im. Oskara Langego we Wrocławiu, Wrocław

Gajewski M., Rola rachunku kosztów w tworzeniu wartości podmiotów leczniczych, praca doktorska w przygotowaniu, Uniwersytet Ekonomiczny we Wrocławiu.

Hass-Symotiuk M., 2014, Zaawansowana rachunkowość podmiotów leczniczych, Wolters Kluwer S.A., Warszawa.

Nowak E., 2016, Rachunek kosztów w jednostkach prowadzacych działalność gospodarcza, Ekspert Wydawnictwo i Doradztwo, Wrocław. 
Nowak E., Wierzbicki M., 2010, Rachunek kosztów. Modele i zastosowania, Polskie Wydawnictwo Ekonomiczne, Warszawa.

Perechuda K., 2007, Dyfuzja wiedzy w przedsiębiorstwie sieciowym. Wizualizacja i kompozycja, Wydawnictwo Akademii Ekonomicznej im. Oskara Langego we Wrocławiu, Wrocław.

Rozporządzenie Ministra Zdrowia z dnia 8 lipca 2015 r. w sprawie zaleceń dotyczących standardu rachunku kosztów u świadczeniodawców, Dz.U. z 2015 r., poz. 1126.

Rudawska I., 2015, Europa seniorów, czyli ryzyko systemowe związane ze starzeniem się populacji, Prace Naukowe Uniwersytetu Ekonomicznego we Wrocławiu, nr 410.

Trentkowska M., 2015, Rachunek kosztów, podstawy rachunkowości zarządczej i zarządzania finansami, SKwP, Warszawa.

Ustawa z dnia 15 kwietnia 2011 r o działalności leczniczej (Obwieszczenie Marszałka Sejmu Rzeczypospolitej z dnia 8 kwietnia 2015 r. w sprawie ogłoszenia jednolitego tekstu ustawy o działalności leczniczej, Dz.U. z 2015 r., poz. 618 z późn. zm.).

www.emc-sa.pl (28.10.2013).

www.healthpowerhouse.com (14.10.2016). 